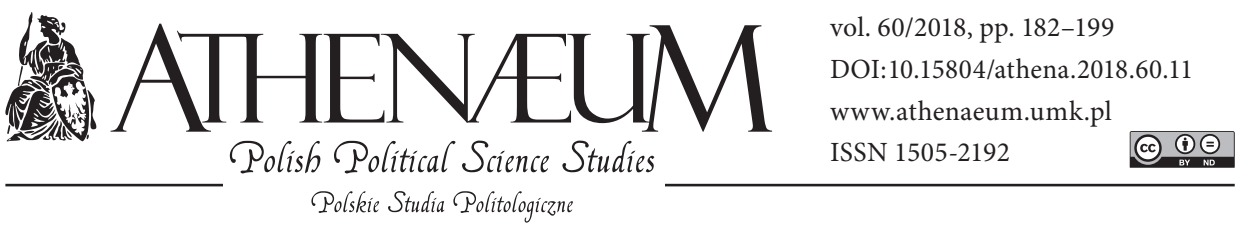

\title{
REGRESS OF THE WEST AND THE EMERGING OF NEW WORLD ORDER: THE CASE OF NATO
}

\author{
REGRES ZACHODU I WYŁANIAJACCY SIĘ NOWY PORZĄDEK \\ ŚWIATOWY. PRZYPADEK NATO
}

Katarzyna Gruszko*®e, Tomasz Gajewski**(1)

\begin{abstract}
Uncertainty is the notion that can be a one-word description of the state of global affairs. Tensions in the world order architecture are symptoms of its ongoing transformation. The purpose of the article is to explore the reasons, manifestations and direction of this change. The prime assumption of the analysis is the regress of the West. NATO as a strategic bridge between two centers of the West - Europe and the United States - is subjected to scientific investigation to examine its possible role in reestablishment of the relative power of the West and regaining its defining capabilities in the world order in statu nascendi. The analysis is supplemented by two scenarios of possible trajectories of world order transformation.
\end{abstract}

Keywords: world order, Western world, NATO, China, international forecast
Jako opis aktualnej sytuacji na świecie może posłużyć jedno słowo - niepewność. Napięcia z niej wynikające są symptomami zmian zachodzących w architekturze porządku światowego. Celem niniejszego artykułu jest zbadanie przyczyn, objawów i kierunków tych zmian. Fundamentem analizy jest obserwowany regres Zachodu. NATO jako strategiczny most łączący dwa jego centra - Europę i Stany Zjednoczone - zostało poddane naukowej eksploracji, by zidentyfikować możliwości jego wykorzystania jako instrumentu przywracającego relatywną siłę Zachodu oraz odtworzenia potencjału określania parametrów wyłaniającego się porządku światowego. Analiza została wzbogacona o dwa scenariusze potencjalnego kierunku transformacji wspomnianego porządku światowego.

Słowa kluczowe: porządek światowy, Zachód, NATO, Chiny, prognozowanie międzynarodowe

* Jan Kochanowski University in Kielce, Faculty of Management and Administration.

** Jan Kochanowski University in Kielce, Faculty of Management and Administration. 


\section{INTRODUCTION}

The West is in retreat - nowadays, this phrase is almost a truism. Europe (embodied by the European Union) and the United States have suffered several grave crises. Western values and institutions are under constant pressure from emerging powers, states as well as non-state actors. These complex, sometimes chaotic processes of global changes converge in broad stream of strategic shift in the world order.

The West, which traditionally defined the conformation of the world, has been pushed to defense (Buzan, 2004, p. 222). Exhaustion and lack of initiative, internal divisions and state of apathy have impact on NATO, regarded as bedrock of Western security and cohesion. What is the role of the West as a whole, and NATO as its "sword" and cooperation forum in times of change? To answer these important questions, analysis of issue of transformation of world order and the role of the West and NATO within it is required. Naturally, the scope of it must be limited.

The article is divided into six substantive sections. Methodology of research and conceptual framework are discussed in separate parts. They are followed by reflection on the nature of world order transformation. In next section, Authors investigate the role of the West in the process of transformation. The most important part represents the probe of NATO position and capabilities to reestablish the strength of the West in global environment. This section is supplemented by two scenarios, presenting alternative trajectories of world order transformation, with emphasis put on the role of the West and NATO.

The literature of the subject is sprawling. Full orientation in the structure of this extensive base of sources is virtually impossible. Therefore, it was required to narrow it decisively. Theoretical works construct the fundament of analysis, framing the methodological lens and conceptual core of the reasoning. The rich collection of monographs, journal articles and analyses prepared by recognized research centers were used to answer raised questions and make attempt to move closer to understanding of the given subject.

\section{METHODOLOGY OF RESEARCH}

The task of identifying trajectories of world order transformations is fraught with serious difficulties. Some argue that certain flaws of social sciences methodological apparatus in that specific discipline is to blame. Nevertheless, it does not 
constitute a reason to abandon it. What is more, it can be conducted within clear, methodological framework. The Authors argue that dynamic political, social, economic and technological transformations can be grasped only within the multileveled paradigm. Consistently with this assumption, the Authors suggest using constructivist approach. It is worth to mention that constructivism, being a critical theory, does not represent a clear opposition to classic approaches ${ }^{1}$.

As leading constructivism scholar Alexander Wendt (1995, pp. 71-72) explained, "the fundamental structures of international politics are social rather than strictly material [...], and that these structures shape actors' identities and interests, rather than just their behavior". Constructivism redefines a set of key variables in international relations: anarchy, balance of power, state interests and behavior, international institutions, patterns of the use of military force and its role itself, trade relations and others have certain social meanings, varying in different contexts (Wendt, 2008, pp. 203-224). However, there is no exclusion of materialistic elements of the structures of international politics. As Wendt (1995, p. 73) writes, "social structures include material resources like gold and tanks". They are not static, they exist in practices. Constructivism treats the world as, how Emanuel Adler (2013, p. 113) puts it, "a project under construction, as becoming rather than being".

Placing the subject in theoretical approach should define the methodology employed to conduct research. Constructivism, due to its ideational character, suggests interpretive methods (Lamont, 2015, pp. 20-21). However, the Authors argue that a combination of different instruments should be used. Constructivism, in the Authors' view, serves as an intellectual lens through which they perceive complexities of the world. It follows Nazli Choucri (1974, p. 65) assumption: "Theory generally performs several functions in the course of empirical investigation: it provides a coding scheme for storing and retrieving information, and it serves as a search instrument which guides the investigator toward the relevant questions and appropriate data".

To realize the objective of the article, the Authors employ international forecasting. According to Choucri (1974, p. 63), "forecasting is a problem of reasoning, of reducing uncertainty, and of bounded and disciplined speculation. Explor-

1 In fact, rivaling paradigms derive various elements from constructivism's “toolbox" (Slaughter, 2011, p. 19). However, there is a specific relationship between constructivism and English School, which acquired some elements of it (Adler, 2013, pp. 119-120). 
ing the unknown, identifying possibilities associated with different outcomes, and isolating likelihoods of occurrences constitutes the essence of forecasting". Andrzej Chodubski (2009, p. 47) designates extrapolation as a primary tool of forecasting. It is based on deduction about "development tendencies, relations, conditions, values" (Sułek, 2010, p. 29). The longest perspective of forecasting is 30-50 years (Sułek, 2010, p. 64). The result of the forecasting process can materialize in the form of scenario. Peter Schwartz (1996, p.4) defines it as a form of "disciplined way of thinking" and "ordering perceptions about alternative future environments". Seyom Brown (1968, pp. 299-300) explains the meaning of scenario as hypothetical parameters of situation within which the actors or complex systems will act.

This highly confined methodological profile of the research constitutes the representation of Authors' scientific tools and rationale behind the selection of data, sources and analytic mechanisms, enabling them to examine the subject.

\section{CONCEPTUAL FRAMEWORK}

Theories of international relations perceive the notion of world order differently. Considerations on the social order have become a starting point for academics to search for the concept of order in the international and global dimension. Characteristic for the liberal approach - spontaneous order, grown not made, Frederik Hayek's kosmos, together with the institutions arise as a result of eliminating inefficient solutions, clashing, not harmonizing the interests (Van de Haar, 2011, pp. 103-104). For Hedley Bull (2012, p. 4), a representative of the English School, order means such a distribution of independent entities that allows the most effective implementation of certain values or goals. He presents the three most important goals of the social order: protection and guarantee of life, truth and property. Order is subordinated to them while at the same time it prevents the implementation of others.

Considerations on the definitions of order and its types are described in rich literature, but the purpose of the article is not to analyze them. However, we should mention the concepts accompanying the reflections on world order, which are indispensable for its understanding: the international community, institutions, and the international system. For Bull, international order will be a concept that is synonymous or identical with the concept of the international community. Barry Buzan, on the other hand, tends to distinguish between the 
system and the system identified with the community. He does it due to both the complexity of the phenomenon, as well as the stages through which the international community has evolved (Buzan, 1993, p. 332). As summarized by Trine Flockhart (2016, pp. 12-13), the liberal international order is a perfect example of the international community. Creating and maintaining order through achieving the abovementioned goals are possible thanks to the primary institution, such as balance of power, international law, diplomacy, and secondary institutions international organizations and regimes.

Another phenomenon is the international system. For constructivism, which in the article is a leading theory, it will be a difficult concept for its social structure is too loose. Here, not international law and institutions, but rather particular interests and coercion, which are material resources, seem to regulate the behavior of states. In contrast to individuals in society, states retain far-reaching autonomy in relation to the system in which they operate, and actions towards other states are often conditioned by internal policy goals and not determined by the system (Wendt, 2008, p.2).

Recourse to material resources can be found in the definition of global order proposed by Henry Kissinger (2017, p. 16), who claims that "world order describes the concept held by a region or civilization about the nature of just arrangements and the distribution of power thought to be applicable to the entire world". So, order consists of a system of recognized principles and a balance of power, which is needed when breaking the above rules. These conditions do not guarantee the elimination of dangerous activities, but they will only occur in exceptional situations, without being a challenge for the whole system. Constructivists claim that the distribution of power affects the behavior and calculations of states, but the question is, to what extent it depends on subjective understanding and expectations and the distribution of knowledge that shapes the perception of yourself and others (Wendt, 1992, p. 397).

Another concept that is important for the considerations is the attempt to define the West. There are various visions of the West, based on military strength, legal and ethical practice, free trade and democracy; most of them assume that the West is the center of the world (Bonnett, 2004, pp. 123-124). The most wellknown approach is defining the West as a civilization, which is embodied in the concept represented by Samuel Huntington. Contemporary cultural and religious differences are indeed reflected in the conduct of politics. On this background, the West appears as an area that seeks to maintain a military and economic advantage by promoting such values as democracy and liberalism 
(Huntington, 2013, p. 9). The use of the term West implies that we are talking about an important and dominant civilization, a community that sets the tone of change at the global level, while others react to actions, decisions, changes of the West (Bonnett, 2004, p. 1).

NATO, as constructivism says, was created on the basis of Atlantic identity in favorable conditions accompanying the formation of a new order after the Second World War. It is an allied organization that can be considered as a platform for cooperation between the Western states ${ }^{2}$, but it is not a regional organization, which causes some difficulties on the one hand, but also gives opportunities. Sharing common roots and putting similar values into practice do not mean that there will be no conflicts between member states (Rynning, 2005, p. 179). On the other hand, such a characteristic of NATO gives the organization opportunities to open up to non-transatlantic democratic states, strengthen the West and adapt to changes in global order (Daalder \& Goldgeier, 2006, p. 106).

Basing on the above reasoning and the objective of the article, the Authors assume that the following hypotheses may be put:

1. Contemporarily, we are witnessing the emergence of the new world order.

2. The position of the West in the emerging new order is uncertain.

3. NATO should remain a guarantor of cohesion of the West.

Basing on the research problem formulated above, the Authors assume that following questions should be raised:

1. What are the driving forces of the world order transformation?

2. What is the character of this transformation?

3. What are the consequences of the transformation of the world order?

4. How to assess the West's share in the process of creation of the new world order?

5. Why the West should not be treated as the Europe and the United States separately?

6. Does the West have potential to become the new world order architect?

2 The so called 'Atlanticism' as an identity arose on the basis of bonds that formed between North America and Europe as a result of migration, trade and political activities. This term accompanies the concept of Western Civilization and its values. Atlanticism is seen as a NATO binder, with pretty idealization of this concept. Taking into account the pragmatic foundations of the Alliance, it can be said that solidarity rather than identity will be a binder of the Atlantic Community. The consequence of this will be the requirement to maintain a constant motivation to cooperate (Long, 2006, p. 26). What is important, NATO's goal was not only to deter the USSR, but also to capture the policies of traditional European powers into a predictable framework and to strengthen the transatlantic ties (Ikenberry, 2008, p. 28). 
7. What are the obstacles to maintain cohesion in NATO?

8. What are the benefits of maintaining cohesion in the Alliance?

\section{THE WORLD ORDER TRANSFORMS}

The notion that the world order undergoes profound transformations is commonly accepted. The most important question is what will be next. An attempt to answer this question demands at least limited analysis of the origins of these changes.

The United States' unipolar moment (Krauthammer, 1990/1991, p. 24), the period of uncontested American hegemony after the Cold War, has ended ${ }^{3}$. In 2008, Thomas Fingar ${ }^{4}$ declared: "the unipolar moment is over; it certainly will be over by 2025" (Office of the Director of National Intelligence Press Briefing, 2008). America has suffered from an imperial overstretch ${ }^{5}$. The relative decline of the second "lung" of the West - the European Union, which suffered severe political, economic and social crises - accelerated the process of degeneration of the world order, driven by Western values.

Technological advances and shifting paradigms of global markets (Schwab, 2016, p. 12) added another layer of changes and contributed to the creation of permissive environment for the transformation of the world order. Richard Haas (2017, p. 2) offers a simple and evocative explanation: "The globe's traditional operating system - call it World Order 1.0 - has been built around the protection and prerogatives of states. It is increasingly inadequate in today's globalized world. Little now stays local; just about anyone and anything, from tourists, terrorists, and refugees to e-mails, diseases, dollars, and greenhouse gases can reach almost anywhere".

Liberal values are on retreat (Ikenberry, 2018, p. 7). President Donald Trump appears to have a desire to "reverse" the globalization. UK's exit from EU structures dealt a serious blow to European integration project. A wave of

3 September 11th attacks can be treated as a form of harbinger of the coming change (Brands, 2016, p. 356).

4 The then Deputy Director of National Intelligence for Analysis and Chairman of National Intelligence Council.

5 It is happening when, as Paul Kennedy explained (1995, p. 496), "the sum total of the United States' global interests and obligations is [...] far larger than the country's power to defend them simultaneously". 
simplistic nationalisms and negation of Western democratic values engulfed large parts of Europe. In consequence of those processes, the West lost its power to define and project the world order's organizing principle. In the period of interregnum between "the old" and "the new", global superstructure resembles Brownian motion, known from physics. The vast network of interactions and overlaps between the state and individual, technological and biological, material and nonmaterial domains gives indication of the direction of world order change. These processes are not happening in a "power vacuum". Multiple crises of the West created a space for new, globally engaged actors. Fareed Zakaria (2008, p. 2) argues that "We are now living through the third great power shift of the modern era. It could be called «the rise of the rest». Over the past few decades, countries all over the world have been experiencing rates of economic growth that were once unthinkable" "The rise of the rest" is of course less evocative than "acceleration" of China, climbing to superpower level, and Russia's renewed aggressiveness.

China, with economic growth and gradual encroachment to new areas, physically and virtually, poses growing challenge. However, the level and complexity of global interdependence puts into question a possibility of open superpower rivalry between the United States and China. Nonetheless, the United States versus China nexus becomes the major fault line in global architecture: "America fears that time is on China's side [...]. Like it or not, the new norms governing how the superpowers will treat each other are being established now. Once expectations have been set, changing them again will be hard" (The Economist, 2018, p. 11). However, China's alleged quest for "reorder" meets a lot of barriers, embodied not only by Western countermeasures ${ }^{6}$. Nevertheless, China's global activities alone contribute to the creation of new rules of world order, even if the hegemony itself may not be its primary goal. Belt and Road Initiative, financial operations in United States and Europe (Tartar, Rojanasakul, \& Diamond, 2018), bridging the gap with Russia (Anderlini, 2018), involvement in Africa (Yu, 2018) and active creation of own regional environment sum in one integrated stream of change.

The world order does not transform swiftly and without tremors. It could be assumed that global economy development, however very fast, is "natural". On

6 According to study prepared by Bentley B. Allan, Srdjan Vucetic, \& Ted Hopf (2018, p. 3), “China is unlikely to be able to attract powerful followers into a counterhegemonic coalition" because of propagandistic and insular discourse. 
the other hand, these overlapping processes produce crises, conflicts and shocks - social, economic, and political. Some say that world is witnessing a global civil war. As Stein Tønnesson (2002, p. 389) argues, "if the term global civil war is applicable, then it presupposes the existence of, or a process leading towards a global society". Complex interdependence, a result of globalization, alone can be identified as a manifestation of the advanced process of global society formation. Therefore, crises and conflicts of our times can be described as battlespaces "rolling" with world order change

Non-state actors are one more vehicle of transformation. Empowered individuals, creating myriad of collective identities - from humanitarian NGOs, through organized political, social and economic actions, to transnational corporations, criminal and terrorist groups (Mason, Conrey, \& Smith, 2007, p. 290) - are autonomous models of exerting influence (Arab Spring is the most striking example). These activities build constraints for traditional actions of states and international organizations, like the UN or NATO. The existence of so condensed communication in cyberspace generates a "world within a world" with its expanding opportunities and, also, expanding threats (information warfare). Overlapping political, social, economic and technological changes create new reality. And, finally, global climate change must also be mentioned as a crucial variable of this complicated equation (Global Trends: Paradox of Progress, 2017, p. 7). The map of "creators of change" mirrors the nature of the change itself.

Global Risk Report, prepared by the World Economic Forum (2018, p. 7), ascertains that "the world has moved into a new and unsettling geopolitical phase. Multilateral rules-based approaches have been fraying [...]. There is currently no sign that norms and institutions exist towards which the world's major powers might converge". The state of overall anxiety and uncertainty prevails. Particularly in the West.

7 For example, the end of America's massive military engagement in the Middle East created a space for new powers, state and non-state actors. Conflicts, like wars in Syria, Yemen and Libya, created "vacuum zones", almost immediately filled by new powers (Russia is the most evocative case). 


\section{THE POSITION OF THE WEST IN THE EMERGING WORLD ORDER IS UNCERTAIN}

During first years after the end of the Cold War, the West, and above all the United States, attempted to create a new order in such a way that the position of the West was sufficiently reflected in it. After the unipolar moment discussed above, the future of the West on the map of globalism and the place in the future order is uncertain. It is necessary to be active in this area, but also to fully recognize and understand the processes of globalization. Until now, the West has been the center of a globalizing world, in the future it may be pushed to its periphery.

So far globalization has been identified with Westernization - the borders were, according to some, extended to the whole world. This was possible due to the high flexibility of the concept of the West, its liberal foundations on which the world order was based after the Second World War. The effect of this is the unobvious role of the West in globalization, as a civilization that is simultaneously expansive and in reverse (Bonnett, 2014, pp. 5-6). Globalization itself is a complex process that brings with it increased interdependence not only between states, but also between non-state actors. The activity of entities is not limited only to sovereign states, but also applies to individuals, companies, corporations and international organizations (Christensen \& Kowalczyk, 2017, p. 2). Intentional creation of world order in the described conditions is a particularly difficult task.

The West is not a single state, but rather it works as a cluster of states led by the United States. Perception of the world, a characteristic approach to international issues and the way of operating will be carried out in an American way, regardless of the diversity within the West. The West will also be identified with the United States in the eyes of external observers. Thus, the typical US hub and spokes construction is a consequence of bringing a complicated world to a readable bilateral division. The assumption that the center of the world is the West, and the center of the West are the US may be wrong. Like the perception of China as the second hub, around which the rest focus and which can only cooperate with the West on its terms, or undermine the leadership of the West, thus leading to conflict. Emerging states are increasingly building their position, "bypassing" the West, weakening the ties connecting them with the system built around the West, striving to create an alternative to it (Barma, Ratner, \& Weber, 2007).

Parag Khanna (2008, pp. 13-14) distinguishes the medium-sized, Second World countries from Eastern Europe, Latin America, the Middle East, Central 
Asia and Southeast Asia. Those are located between the center and the periphery of globalism. He emphasizes that they strive to use globalization without the brokering of superpower, while their current geopolitical position allows equally good cooperation with the United States, Western Europe and China. Despite some weaknesses, they are able to play a sufficiently important role in international relations.

Importantly, the position of the United States is weakening, which puts the West ahead of new challenges. The question is whether in the new conditions it will retain the ability to react and create new solutions to the problems of world trade, work, the natural environment, challenges for particular interests and, at the same time, Western civilization values. The second question is about the faith in the strength of the West among Western countries - an element necessary to maintain leadership in the world (Khanna, 2008, p. 17). Narrowing the problem to only "the rise of the rest" or looking for a source of problems only in Others is inadequate and will not meet the challenges of the $21^{\text {st }}$ century. This problem is not ideological or civilizational and requires an answer to the question of how, not what to respond to the challenges of globalization (Rose, 2012, p. 6).

It seems that in the current international conditions it is important to maintain the cohesion of the West. The cohesion of the West depends to a large extent on determining the differences between the US and Europe. They result from both historical and cultural differences, as well as from the positions of individual states. The global power will present a different view of the stability of the order or the preservation of the status quo than medium states. The global power has greater possibilities for undertaking unilateral actions, while European states must cooperate with each other - therefore, on the one hand, we are dealing with the pursuit of national interest in global politics and, on the other hand, with the implementation of the common interest. What is more, Americans sustain this diversity and use it in political discourse - it becomes a platform for emphasizing American exceptionalism (Herms Drath, 2006, p. 427).

An attractive solution may be a new regionalism, which is not so much a theory but a broad intellectual movement that treats changes in regionalism in conditions of enhanced globalization. It is also a response to the lack of adjustment of regionalism to new challenges, institutional formalization, structures, and lack of recognition of non-state actors (Acharya, 2012, p. 8). New regionalism has a bottom-up character and non-state actors have a significant influence on its course. It has an open character and is not perceived through the prism of geographical proximity. It is rather a subjective community of entities involved in 
the process (Larner \& Walters, 2002, p. 393). With regard to the West, it is possible to create bonds through cooperation. However, it would require states to redefine their goals, interests and identity by assimilating new values in conditions of mutual understanding (Wunderlich, 2007, p. 39). While old regionalism took place in the conditions of bipolar international order, the modern can take place under the conditions of multipolarity (Hettne, 1997, p. 85).

The liberal world order created after the Second World War was based on international institutions. International organizations are not only tools for carrying out national interests of individual states but remain a separate participant in international relations. Importantly, not only are states impact institutions, but organizations are also able to transfer certain values and principles to the state level. By creating regimes, international institutions have the ability to evolve, adapt to changing challenges and transform their goals of functioning in such a way as to be effective (Ratti, 2006, pp. 86-87).

In the light of the above, two problems can be identified that accompany the creation and evolution of the world order. The first of these is the cost of achieving global goals, which are borne by the powers in whose interest it is to preserve the existing order. Setting up international organizations and including them in the international system is one of the ways to minimize the global leader's burden. On the other hand, assigning responsibility to international organizations can be used by the contenders for the status of a global power, in whose interest lies the revision of the existing order. However, the costs and possibilities of creating new organizations are very high and it is easier to modify existing institutions to better suit their interests than to create new ones (Czaputowicz, 2007, pp. 171-172). In this way, international organizations will decide on the durability of world order. By mapping the values promoted by the strongest powers at the time of the creation, they will preserve their position in the conditions of the evolving world order. Any state that would like to make changes to the existing order would have to create, instead of the old ones, its own system of international organizations. Otherwise, the existing system of international organizations will remain the tool of control of the previous leader, limiting the opportunities of new ones (Frankowski, 2010, pp. 107-108).

Building an alternative to a global organization still seems impossible in the near future, even for China, but building an alternative to Western European particular organizations seems to be in line with the interests of the strongest powers. Establishment of the Shanghai Cooperation Organization (SCO) under the leadership of China and Russia, also called NATO of the East, its activity 
not only as an alliance, but also as a platform for cooperation in the field of trade, entrepreneurship and broadly understood security for Central Asia, Iran, Afghanistan and Pakistan, might be an example. The SCO takes action to stabilize the situation in Afghanistan, i.e., where NATO failed. The Asian order was built in the past on the American hub and spokes construction, while today the initiative to build regional order in the area between India, Japan and Australia is taken over by China (Khanna, 2008, pp. 14-16). In the light of the above, the reform and enlargement of NATO to states outside Europe and North America seems desirable. Among the proposals, you can find Global NATO or the League of Democracies. The latter would support peace, associate nations with similar values that would commit to not use force against each other, and among whom the US would seek support for military interventions. The League of Democracies would serve to rebuild the credibility of the United States by listening to other, seriously treating partnerships and renouncing the temptation of unilateral actions (Carothers, 2008, p. 2).

\section{NATO - A GUARANTOR OF WESTERN COHESION}

NATO integrates states with different strategic culture, and what is most important, with differentiated interests and perception of the security environment. There is a strong variation in threat recognition in globally engaged Unite States, south-oriented Italy, and Poland or Baltic states living in the shadow of Russia. Transformation of global order, shifting center of gravity of international relations to Asia-Pacific region add another layer of anxiety and uncertainty in the NATO members. Crisis of the West is felt in some states as a cause of creating own security guaranties and renationalization of policies (Webber, Hallams, \& Smith, 2014, p. 780). The observing process of repositioning United States' resources to Asia is the reason of fear in European NATO members.

From the global point of view, there is a necessity that West stays as one entity within the transforming world order. According to global circumstances, it is required that NATO acts as a one global player, despite the differences between particular states and nations. Such posture will without doubt strengthen not only the West itself but also NATO members, both weaker and stronger ones.

It is therefore justified to sketch two alternative scenarios of the future world order, where the position of NATO serves as bedrock of the West or just an atomized grouping of the states. 


\begin{tabular}{|c|c|}
\hline & ГО \\
\hline $\begin{array}{l}\$ \text { Globalization keeps spreading Western values. } \\
\S \text { Westernization blocks expansion of other } \\
\text { civilizations (i.e., China). } \\
\S \text { European integration project is reinvigorated. } \\
\text { The United States remain the global power but } \\
\text { with reduced burdens. The soft power of the } \\
\text { West serves as tool to pursue of common and } \\
\text { particular interests. } \\
\S \text { The dynamics of NATO exceeds the borders of } \\
\text { Euro-Atlantic area - Global NATO (Australia, } \\
\text { New Zealand, Japan, South Korea). } \\
\S \text { NATO Second States stay in, and those from } \\
\text { outside (i.e., Middle East, Central Asia and } \\
\text { Southeast Asia) aspire to join the West not } \\
\text { defined by the race. } \\
\$ \text { The new world order is replenished by the Fo- } \\
\text { urth Technological Revolution, which empowers } \\
\text { non-state actors (NGOs, enterprises, grassroots } \\
\text { movements and individuals). The West recogni- } \\
\text { zes those new actors and understands their role } \\
\text { and capabilities. } \\
\$ \text { The West possesses well-developed strategic } \\
\text { awareness (logos before pathos). } \\
\S \text { The new complex world order emerges with } \\
\text { multipolarity as an organizing principle but } \\
\text { controlled by a single power (i.e., the integrated } \\
\text { West). } \\
\$ \text { The reformed UN, built upon the Western values, } \\
\text { remains a spine of the world order. }\end{array}$ & $\begin{array}{l}\$ \text { Globalization cease to spread Western values. } \\
\$ \text { Globalization starts to be a tool of expansion of } \\
\text { other civilizations (i.e., China). } \\
\S \text { European integration project loses its dynamics. } \\
\text { The United States is no longer a global power. } \\
\text { Their hard power suffers severe blow. } \\
\$ \text { The vacuum zone emerges, and it is filled out } \\
\text { by the new global powers/civilizations with their } \\
\text { own values. } \\
\$ \text { The Second States members of NATO are no } \\
\text { longer motivated for cooperation within the } \\
\text { West. They are eager to join some other projects. } \\
\$ \text { Using clichés, while in global game deforms } \\
\text { perception and judgment of international } \\
\text { environment. Non-state actors and empowe- } \\
\text { red individuals, under conditions of Fourth } \\
\text { Industrial Revolution, serve unrecognized role in } \\
\text { construction of the new world order. } \\
\$ \text { Bullheaded operating the myth of the West as } \\
\text { a center of the world generates severe threats. } \\
\$ \text { Without a "plan B", the West as a global player } \\
\text { disappears. } \\
\$ \text { Rebuilding the position of the United States and } \\
\text { European states is extremely difficult and costly } \\
\text { (even impossible). } \\
\$ \text { The structure of the new world order reflects } \\
\text { incomprehensible, non-Western system of } \\
\text { values. The soft power of the West is virtually } \\
\text { nonexistent. } \\
\$ \text { The new complex world order emerges with } \\
\text { multipolarity as an organizing principle but } \\
\text { controlled by a single power (i.e., China). }\end{array}$ \\
\hline
\end{tabular}

\section{CONCLUSION}

Nowadays we are witnessing the decline of the West, because of the incongruity between the descending nation-state system and the world order in statu nascendi, China's quest for global power status and the "rise of the rest". The processes take place within different conditions than it happened previously (new actors, environment defined by technological revolution). International institutions no longer correspond with new challenges and circumstances. As a consequence, we 
are facing an uncertainty and tension that could lead to an open global conflict. The West still remains a global player though its capabilities are limited. It is not a homogenous unit, though Euro-Atlantic nations should strive for cohesion. It is sine qua non for maintaining the West's share and not to be pushed off the mainstream of globalism. The position of the West in emerging world order depends on the recognition of the transformation and taking an active role in the process. Inertia to those opportunities is tantamount to new distribution of power that does not reflect the West capabilities. NATO may work as one of the tools to maintain Western integrity, though it requires reforming. We are living in the decisive period so exact steps must be taken.

\section{REFERENCES:}

Acharya, A. (2012). Comparative Regionalism: A Field Whose Time Has Come? The International Spectator, 47(1), 3-15. DOI: 10.1080/03932729.2012.655004.

Adler, E. (2013). Constructivism in International Relations: Sources, Contributions, and Debates. In: W. Carlsnaes, T. Risse, \& B.A. Simmons (eds.), Handbook of International Relations (pp. 112-145). London: Sage.

Allan, B.B, Vucetic, S., \& Hopf, T. (2018). The Distribution of Identity and the Future of International Order: China's Hegemonic Prospect. International Organization, 72(4), 839-869. DOI: $10.1017 /$ S0020818318000267.

Anderlini, J. (2018). China and Russia's Dangerous Liaison. Retrieved from: https://www. ft.com/content/1b4e6d78-9973-11e8-9702-5946bae86e6d.

Barma, N., Ratner,E., \& Weber, S. (2007). Report and Retort: A World Without the West. The National Interest. July 1 . Retrieved from: https://nationalinterest.org/article/reportand-retort-a-world-without-the-west-1658?fbclid=IwAR1kA7vwHzc-aDNP5hRuaIBWaHp5DY1krVN-H0S28BWQJ-54bbHTT5INJY.

Bonnett, A. (2004). The Idea of the West: Culture, Politics and History. New York: Palgrave Macmillan.

Brands, H. (2016). Making the Unipolar Moment: U.S. Foreign Policy and the Rise of the Post-Cold War Order. New York: Cornell University Press.

Brown, S. (1968). Scenarios in System Analysis. In: E.S. Quade, \& W.I. Boucher (eds.), Systems Analysis and Policy Planning: Applications in Defense. A Report Prepared for United States Air Force Project Rand (pp. 298-311). New York: American Elsevier Publishing Company, Inc.

Bull, H. (2012). The Anarchical Society: A Study of Order in World Politics. Basingstoke, New York: Palgrave Macmillan.

Buzan, B. (1993). From International System to International Society: Structural Realism and Regime Theory Meet the English School. International Organization, 47(3), 327-352. 
Carothers, T. (2008). Is a League of Democracies a Good Idea? Carnegie Endowment for International Peace. Foreign Policy for the Next President. May 19. Retrieved from: https://carnegieendowment.org/2008/05/19/is-league-of-democracies-good-ideapub-20135.

China v America (2018). The Economist, 429(9114).

Chodubski, A. (2009). Prognostyka jako wyzwanie metodologiczne w badaniu stosunków międzynarodowych. Annales Universitatis Mariae Curie-Skłodowska, 16(2), 41-57.

Choucri, N. (1974). Forecasting in International Relations: Problems and Prospects. International Interactions, 1(2), 63-86. DOI: 10.1080/03050627408434390.

Christensen, B.J., \& Kowalczyk, C. (2017). Introduction to Globalization: Strategies and Effects. In: B.J. Christensen, \& C. Kowalczyk (eds.), Globalization: Strategies and Effects (pp. 1-16). Berlin: Springer.

Czaputowicz, J. (2007). Teorie stosunków międzynarodowych. Warszawa: PWN.

Daalder, I., \& Goldgeier, J. (2006). Global NATO. Foreign Affairs, 85(5), 105-113. DOI: $10.2307 / 20032073$.

Flockhart, T. (2016). The Coming Multi-Order World. Contemporary Security Policy, 37(1), 3-30. DOI: 10.1080/13523260.2016.1150053.

Frankowski, P. (2010). One World - Many “Orders”? In: S.F. Krishna-Hensel (ed.), Order and Disorder in the International System (pp. 97-115). Aldershot: Ashgate.

Global Risk Report (2018). Geneva: World Economic Forum.

Global Trends: Paradox of Progress (2017). Washington, D.C.: National Intelligence Council.

Haass, R. (2017). World Order 2.0: The Case for Sovereign Obligation. Foreign Affairs, 96(1), 2-10.

Herms Drath, V. (2006). Toward a New Atlanticism. American Foreign Policy Interests, 28(6), 425-431. DOI: 10.1080/10803920601072017.

Hettne, B. (1997). Development, Security and World Order: A Regionalist Approach. The European Journal of Development Research, 9(1), 83-106. DOI: $10.1080 / 09578819708426678$.

Huntington, S. (2013). The Clash of Civilizations? In: Foreign Affairs Collection: The Clash at 20 (pp.3-28). Retrieved from: http://home.sogang.ac.kr/sites/jaechun/ courses/Lists/b6/Attachments/9/clash\%20of\%20civilization.pdf.

Ikenberry, G.J. (2008). State Power and International Institutions: America and the Logic of Economic and Security Multilateralism. In: D. Bourantonis, K. Ifantis, \& P. Tsakonas (eds.), Multilateralism and Security Institutions in an Era of Globalization (pp. 21-42). London and New York: Routledge.

Ikenberry, G.J. (2018). The End of Liberal International Order? International Affairs, 94(1), 7-23. DOI: 10.1093/ia/iix241.

Kennedy, P. (1994). Mocarstwa świata. Narodziny, rozkwit i upadek. Warszawa: Książka i Wiedza.

Khanna, P. (2008). Here Comes the Second World. New Perspectives Quarterly, 25(3), 13-17. DOI: 10.1111/j.1540-5842.2008.00994.x. 
Kissinger, H. (2017). Porządek światowy. Wołowiec: Wydawnictwo Czarne.

Krauthammer, C. (1990/1991). The Unipolar Moment. Foreign Affairs, 70(1), 23-33.

Lamont, C. (2015). Research Methods in International Relations. London: Sage.

Larner, W., \& Walters, W. (2002). The Political Rationality of "New Regionalism":

Toward a Genealogy of the Region. Theory and Society, 31(3), 391-432. DOI: 10.1023/A:1016255120209.

Long, D. (2006). NATO after Atlanticism. In: O. Croci, \& A. Verdun (eds.), The Transatlantic Divide: Foreign and Security Policies in the Atlantic Alliance from Kosovo to Iraq (pp. 19-35). Manchester, New York: Manchester University Press.

Mason, W.A., Conrey, F.R., \& Smith, E.R. (2007). Situating Social Influence Processes: Dynamic, Multidirectional Flows of Influence within Social Networks. Personality and Social Psychology Review, 11(3), 279-300. DOI: 10.1177/1088868307301032.

Office of the Director of National Intelligence Press Briefing 2008. November 20. Retrieved from: https://www.dni.gov/files/documents/Newsroom/Speeches $\% 20$ and $\% 20$ Interviews/20081120_interview.pdf.

Ratti, L. (2006). Post-Cold War NATO and International Relations Theory: The Case for Neo-Classical Realism. Journal of Transatlantic Studies, 4(1), 81-110. DOI: $10.1080 / 14794010608656841$.

Rose, G. (2012). Making Modernity Work: The Reconciliation of Capitalism and Democracy. In: G. Rose, \& J. Tepperman (eds.), The Clash of Ideas: The Ideological Battles that Made the Modern World - And Will Shape the Future (pp. 2-20). New York: Council on Foreign Relations, Inc.

Rynning, S. (2005). NATO Renewed: The Power and Purpose of Transatlantic Cooperation. New York, Houndmills: Palgrave Macmillan.

Schwab, K. (2016). The Fourth Industrial Revolution. Geneva: World Economic Forum.

Schwartz, P. (1996). The Art of the Long View: Planning for the Future in an Uncertain World. New York: Currency Doubleday.

Slaughter, A.M. (2011). International Relations, Principal Theories. Retrieved from: https://www.princeton.edu/ slaughtr/Articles/722_IntlRelPrincipalTheories_ Slaughter_20110509zG.pdf.

Sułek, M. (2010). Prognozowanie i symulacje międzynarodowe. Warszawa: Wydawnictwo Naukowe Scholar.

Tartar, A., Rojanasakul, M., \& Diamond, J.S. (2018). How China Is Buying Its Way into Europe. Retrieved from: https://www.bloomberg.com/graphics/2018-chinabusiness-in-europe/.

The North Atlantic Treaty, Washington D.C., 4 April 1949 (2018). Retrieved from: https:// www.nato.int/cps/en/natolive/official_texts_17120.htm.

Tønnesson, S. (2002). A 'Global Civil War'? Security Dialogue, 33(3), 389-391.

Tzifakis, N. (2012). Change in International Politics: An Introduction to the Contemporary Debate. In: N. Tzifakis (ed.), International Politics in Times of Change (pp. 1-14). Heidelberg, Dordrecht, London, New York: Springer. DOI: 10.1007/9783-642-21955-9_1. 
Van de Haar, E. (2011). Hayekian Spontaneous Order and the International Balance of Power. The Independent Review, 16(1), 101-118.

Webber, M., Hallams, E., \& Smith, M.A. (2014). Repairing NATO's Motors. International Affairs, 90(4), 773-793. DOI: 10.1111/1468-2346.12140.

Wendt, A. (1992). Anarchy Is What States Make of It: The Social Construction of Power Politics. International Organization, 46(2), 391-425. DOI: 10.1017/ S0020818300027764.

Wendt, A. (1995). Constructing International Politics. International Security, 20(1), 71-81. DOI: $10.2307 / 2539217$.

Wendt, A. (2008). Społeczna teoria stosunków międzynarodowych. Warszawa: Wydawnictwo Naukowe Scholar.

Wunderlich, J.U. (2007). Regionalism, Globalization and International Order: Europe and Southeast Asia. Hampshire, Burlington: Ashgate Publishing Limited.

Yu, L. (2018). China's Expanding Security Involvement in Africa: A Pillar for 'ChinaAfrica Community of Common Destiny'. Global Review, 9(4), 489-500. DOI: 10.1111/1758-5899.12585. 